\title{
Cânone Romântico Brasileiro: exclusão das lutas indígenas e suas implicações para o presente
}

\section{Brazilian Romantic Canon: exclusion of indigenous claims and their implications for the present}

\author{
Enviado em: 30/09/2020 \\ Aceito em: 05/01/2021
}

Suene Honorato ${ }^{1}$

\section{Resumo}

Gonçalves Dias e José de Alencar, os dois autores mais conhecidos do romantismo brasileiro, construíram obras literárias em que o indígena figura como vítima de um passado histórico. Já nas obras de autores como Lourenço Amazonas, Couto de Magalhães e Gonçalves de Magalhães, hoje pouco lembradas, pode-se encontrar um indígena que atua como agente histórico, em disputa com o colonizador. A análise da representação indígena nas obras desse conjunto de autores, tendo em vista a distinção entre política indigenista e política indígena (CUNHA, 2012), me permitirá discutir em que medida a produção do reconhecimento (política literária) tem implicações nos modos de se pensar a questão indígena no presente.

Palavras-chave: Romantismo; Brasil; Indígena; Representatividade.

\begin{abstract}
Gonçalves Dias and José de Alencar, the two best-known authors of Brazilian romanticism, built literary works in which the indigenous figure is the victim of a historical past. In the works of authors like Lourenço Amazonas, Couto de Magalhães and Gonçalves de Magalhães, today little remembered, one can find an indigenous person who acts as a historical agent, in dispute with the colonizer. The analysis of indigenous representation in the works of this group of authors, in view of the distinction between indigenous and indigenous politics (CUNHA, 2012), will allow me to discuss to what extent the production of recognition (literary politics) has implications for the ways of thinking the indigenous issue in the present.
\end{abstract}

Keyword: Romanticism; Brazil; Indigenous; Representativeness.

\section{Política indigenista, política indígena e política literária}

Em "Introdução a uma história indígena", a antropóloga Manuela Carneiro da Cunha distingue "política indigenista" de "política indígena": a primeira diz respeito à

1 - Profa. do Departamento de Literatura da Universidade Federal do Ceará (UFC). Doutora em Teoria e História Literária pela Universidade Estadual de Campinas (Unicamp). Desenvolve pesquisa sobre "personagens indígenas nas literaturas brasileiras". 
atuação dos poderes institucionais que, "por má consciência e boas intenções" (2012, p. 22), consolidaram a ideia de que os "índios" ${ }^{2}$ foram/são vítimas do sistema; a segunda traz para o primeiro plano "os índios como agentes de sua história" (2012, p. 24). Ainda segundo a autora, lida a contrapelo a história revela que a política indigenista se valeu muitas vezes da política indígena (alianças e rivalidades entre grupos distintos, por exemplo) para concretizar seus objetivos, contrários à autodeterminação dos povos.

Essa distinção entre política indigenista e política indígena me parece útil para pensar autores do romantismo brasileiro - primeiro momento de afirmação programática da identidade nacional por meio da literatura. Ela me permitirá discutir como a produção de reconhecimento desses autores, isto é, a política literária, tem implicações nos modos de se pensar a questão indígena no presente. Cada um dos cinco autores mencionados aqui mereceria um estudo à parte. Para a discussão nos limites deste texto, no entanto, farei apenas breves comentários sobre trechos emblemáticos de suas obras. A síntese será necessária para levar adiante minha hipótese de leitura, mas obviamente tal hipótese não dispensa uma leitura detalhada das obras referidas, que pode apontar outros aspectos relevantes para a compreensão do que estou propondo. Trata-se de uma reflexão em processo.

De modo geral, os cinco autores que reúno - Gonçalves Dias [1823-1864], José de Alencar [1829-1877], Lourenço Amazonas [1803-1864], Couto de Magalhães [1837-1898] e Gonçalves de Magalhães [1811-1882] - representam poderes institucionalizados em relação à questão indígena: são parte da "meia dúzia" de pessoas que compunha a elite letrada no século XIX, responsável por produzir conhecimento sobre o Brasil pós-independência e assessorar as decisões do governo central. Nesse sentido, todos eles são atores da política indigenista durante o Brasil Império. No entanto, das obras que ficaram à margem do cânone, uma leitura a contrapelo pode colocar a política indígena no primeiro plano (ainda que a serviço da política indigenista). Assim, a comparação entre obras lembradas e obras esquecidas permite levantar outras motivações inscritas na política literária, que não somente as ditas estéticas, para a permanência das obras no cânone.

2 - Utilizo a palavra "índio", conforme citação da autora. Nos textos do século XIX, citados neste artigo, encontraremos o mesmo termo para designar o que hoje mais propriamente talvez chamássemos de indígenas ou povos originários. A recusa do termo "índio" por representantes do movimento indígena hoje diz respeito ao estereótipo que ele evoca - a partir do equívoco da "descoberta" do Brasil, quando os portugueses acreditavam estar chegando às Índias -, omitindo a diversidade cultural dos povos originários. No entanto, ele não deixa de ser usado pelos mesmos representantes, pois é uma categoria (ao menos no plano jurídico) importante para pensar o Brasil. 


\section{Lembrados: Gonçalves Dias e José de Alencar}

Antônio Gonçalves Dias e José Martiniano de Alencar são os dois autores mais conhecidos do romantismo brasileiro - aqueles que aparecem em livros didáticos, considerados imprescindíveis para um estudo da história literária no período. Suas obras podem ser lidas como denúncia da violência no contato entre colonizador e colonizado, ao mesmo tempo em que naturalizam essa violência. Um primeiro elemento dessa naturalização é o fato de ambos os autores, em textos literários e não literários, se referirem aos indígenas como "raça extinta". Outro elemento, já dentro de suas obras literárias, está na representação das personagens indígenas como figuras que ou reconhecem a inevitabilidade da dominação ou se rendem a ela sem resistência. A naturalização do extermínio indígena se faz necessária ao "desenvolvimento" da nação brasileira, ancorado na ideia de que o "branco" é o elemento civilizador.

Nos Primeiros cantosde Gonçalves Dias (2000, p. 11), publicados em 1846, a seção "Poesias americanas" traz poemas como "O canto do Piaga"; nele, o Piaga relata a visão de um fantasma que, anunciando tempos ruins, lhe questiona: "Por que dormes, ó Piaga divino?". A desgraça anunciada pelo fantasma é a chegada de um "monstro" pelos mares, que "Vem matar vossos bravos guerreiros, / Vem roubar-vos a filha, a mulher!" (DIAS, 2000, p. 12). Sendo o Piaga aquele que faz a mediação entre o mundo dos vivos e o mundo dos mortos, responsável pela cura física e espiritual da comunidade, o questionamento do fantasma, atribuindo ao sábio indígena inação diante da tragédia anunciada, o torna responsável por ela. A tragédia se efetivará porque o Piaga foi incapaz de agir. "Deprecação" reforça a hipótese de que os indígenas são responsabilizados pela própria extinção. A voz poética se dirige a Tupã, suplicando que o deus interrompa a vingança: "Tupã, ó Deus grande! teu rosto descobre: / Bastante sofremos com tua vingança" (DIAS, 2000, p. 16). O passado de glória dos Tupi é contraposto ao presente, em que a morte levou tantos guerreiros que "Já restam bem poucos dos teus, qu'inda possam / Dos seus, que já dormem, os ossos levar" (DIAS, 2000, p. 17) - triste imagem em que os vivos não são suficientes para fazer o luto dos mortos. O genocídio indígena é justificado porque Tupã está insatisfeito e permitiu que Anhangá trouxesse pessoas que vêm de longe para destruílos, embora não se explicite o motivo da insatisfação do deus. Em "O canto do Piaga" e "Deprecação", portanto, há um esforço em ficcionalizar a narrativa do contato a partir 
do olhar indígena, que seria sujeito da própria história; o resultado, porém, é que a voz indígena é culpabilizada pelo próprio extermínio. Assim, o sujeito se enuncia como objeto passivo da violência.

Em "O gigante de Pedra" - poema que integra as "Poesias americanas" dos Últimos cantos, de 1851 -, uma voz poética distanciada rememora as "fases" da história indígena: um tempo de "homéreas festas" (DIAS, 2000, p. 297), ao qual segue "o gérmen da discórdia" (DIAS, 2000, p. 298) entre povos indígenas, e depois a chegada de "naus flamívomas" (DIAS, 2000, p. 298). No poema, as guerras entre povos indígenas fazem que eles se dispersem por "matas ínvias", restando "[...] o pajé sem glória, / Sem glória o maracá" (DIAS, 2000, p. 298). O gigante referido no título do poema é o espectador inerte da história pátria: "Porém se algum dia fortuna inconstante / Puder-nos a crença e a pátria acabar, / Arroja-te às ondas, ó duro gigante, / Inunda estes montes, desloca este mar!" (DIAS, 2000, p. 299). O genocídio indígena, iniciado pela disseminação do "gérmen da discórdia" e completado pela colonização, não acorda o gigante, isto é, não perturba a história pátria, já que essa possibilidade aparece no poema como algo futuro. Em relação ao genocídio indígena, o gigante permanece inerte; o genocídio indígena é parte necessária à formação da pátria, compõe o destino da nação.

A ideia de "gérmen da discórdia" está presente também no poema indianista mais conhecido de Gonçalves Dias: "I Juca-Pirama", o terceiro na série das "Poesias americanas" dos Últimos cantos. Prisioneiro dos Timbira, o guerreiro Tupi pede que seu ritual de morte seja adiado para que possa cuidar do pai cego e doente; os dois são os últimos de um povo que, portanto, é representado como em vias de desaparecer. A adesão à vingança guerreira está no primeiro plano como justificativa do seu desaparecimento.

Outra versão para a justificativa do genocídio indígena na obra de Gonçalves Dias aparece em "O canto do índio", dos Primeiros cantos. Narrado em primeira pessoa, o poema conta a história de um indígena que se apaixona por uma mulher branca tão logo a vê. A paixão faz que o índio suporte sacrifícios sem se queixar e se disponha a abandonar sua família e sua cultura para segui-la. A solução final é a seguinte: "Odeio tanto aos teus, como te adoro; / Mas queiras tu ser minha, que eu prometo / Vencer por teu amor meu ódio antigo, / Trocar a maça do poder por ferros / E ser, por te gozar, escravo deles" (DIAS, 2000, p. 15). A sujeição do índio àqueles que considera inimigos históricos é, no poema, uma decisão individual e inevitável, suscitada por uma paixão avassaladora. Num contexto em que a literatura assumiu a 
função de construir um sentimento de unidade no país recém independente, é preciso ler no poema mais do que uma situação específica: ela sobressai como metáfora da miscigenação entre o branco e o indígena enquanto pilares da identidade brasileira, de onde o negro é sistematicamente excluído. Aqui estaria uma primeira versão do "mito sacrificial" (BOSI, 1992), que será depois desenvolvida em O Guaranie Iracema, de José de Alencar.

Tomo de empréstimo a expressão de Alfredo Bosi para estabelecer uma continuidade entre a obra de Gonçalves Dias e a de José de Alencar, sabendo que o crítico discordaria do uso que faço. Bosi acredita que os poemas de Gonçalves Dias representam a dimensão trágica do encontro entre portugueses e indígenas, ao passo que a obra de José de Alencar a teria amenizado e diluído; por isso, Alencar ofereceria uma leitura interessada à política do Brasil império e "pesadamente ideológica como interpretação do processo colonial” (BOSI, 1992, p. 179), não verificável na obra de Gonçalves Dias. Já Paulo Franchetti (2007), observando as alterações que Gonçalves Dias fez nas "Poesias americanas" entre as edições dos Primeiros cantos, conclui que o poeta respondeu à expectativa do indianismo no plano nacional, que consistia em apagar o indígena do presente para que ele não fosse identificado às revoltas populares que então estouravam. A considerar as duas perspectivas críticas, tanto Gonçalves Dias quanto José de Alencar contribuíram para fabricar uma interpretação do Brasil que convinha às elites no poder. A denúncia da violência contra os povos indígenas, que Bosi considera presente na obra de Gonçalves Dias e ausente na de Alencar, não é menos pesadamente ideológica, pois ela trabalha em prol da política indigenista ao representar os indígenas como vítimas de um processo histórico acabado. A denúncia segue reconhecendo-os como "raça extinta".

Nos romances O Guarani e Iracema, de José de Alencar, a presença do discurso cristão compõe a justificativa da assimilação dos povos indígenas para o bem da nação. Em O Guarani, publicado em 1857, Peri vê em Cecília uma duplicação da imagem de Nossa Senhora. A partir de então, abandona sua família e sua cultura para ser seu fiel escravo. A dedicação é exaltada pelo pai da moça, dom Antônio de Mariz, que reconhece em Peri um "cavalheiro português no corpo de um selvagem" (ALENCAR, 1958b, p. 70). Há um longo caminho para que Cecília aceite o amor de Peri, o que só acontece nas últimas páginas do romance, quando toda a família portuguesa fora destruída pelos aimorés e Peri tentava fazer Cecília chegar ao Rio de Janeiro, onde ela iria em busca do irmão, Diogo. Mas Cecília se reconhece filha da floresta e na floresta decide ficar com o "irmão" que elegera: Peri. Quando o rio 
começa a encher, o par romântico é alçado a um cenário mítico, fora do tempo, em que Peri conta a Cecília a história de Tamandaré, antepassado indígena que sobrevive a um dilúvio para fundar a nova humanidade. O romance termina com o casal se beijando no olho da palmeira que flutua sobre o dilúvio. Embora o romance termine em suspenso, a narrativa de Tamandaré funciona como prefiguração da nova identidade: de Cecília e Peri nasceriam os primeiros brasileiros.

A assimetria entre a representação do branco e do indígena em O Guarani, em que a formação da nova identidade exige que o segundo se sacrifique pelo primeiro, é reforçada em Iracema, publicado em 1865. Como Peri por Cecília, Iracema por Martim abdica da função social que desempenha entre o seu povo. Guardiã do segredo da Jurema, a virgem de Tupã se sabe impedida de amar. Ela diz sobre si mesma: "O mel dos lábios de Iracema é como o favo que a abelha fabrica no tronco da andiroba: tem na doçura o veneno" (ALENCAR, 1958a, p. 251); e o pajé diz também que "Se a virgem abandonou ao guerreiro branco a flor de seu corpo, ela morrerá [...]" (ALENCAR, 1958a, p. 257). Desde a chegada do "guerreiro branco", a tristeza de Iracema é permanente: tanto porque sua função a impede de amar, quanto porque Martim oscila entre dois amores.

\begin{abstract}
Martim se embala docemente; e, como a alva rede que vai e vem, sua vontade oscila de um a outro pensamento. Lá o espera a virgem loura dos castos afetos; aqui lhe sorri a virgem morena dos ardentes amores.

Iracema recosta-se langue ao punho da rede; seus olhos negros e fúlgidos, ternos olhos de sabiá, buscam os do estrangeiro e lhe entram n'alma. O cristão sorri; a virgem palpita; como o saí, fascinado pela serpente, vai declinando o lascivo talhe, que se debruça enfim sobre o peito do guerreiro (ALENCAR, 1958a, p. 266).
\end{abstract}

No trecho, a distinção entre afetos "castos" e "ardentes" marca um preconceito racial, que também ocorre em $O$ Guarani, entre Cecília (branca, casta) e Isabel (mestiça, lasciva) ${ }^{3}$ A metáfora do saí fascinado pela serpente sugere, nas posições de presa e predador, a violência do contato, como, de resto, em muitas passagens do romance ${ }^{4}$. Iracema, depois de ter abandonado os parentes para viver com Martim, definha enquanto nasce Moacir, "o filho da dor". No final do romance, Martim, tendo passado uns anos em Portugal com Moacir, retorna ao Brasil para fundar a "mairi dos cristãos" (ALENCAR, 1958a, p. 303) com o apoio de seu amigo Poti, convertido e

3 - Conferir o capítulo V (“Loura e morena”) da primeira parte de O Guarani.

4 - Lucia Helena (2006), em A solidão tropical, dedica especial atenção a essas figurações na obra alencarina. 
batizado, para dar combate ao "feroz tupinambá"5 (ALENCAR, 1958a, p. 304). Assim, "a mairi que erguera à margem do rio, nas praias do Ceará, medrou. Germinou a palavra do Deus verdadeiro na terra selvagem e o bronze sagrado ressoou nos vales onde rugia o maracá" (ALENCAR, 1958a, p. 304). Iracema é esquecida até mesmo pela jandaia que cantou seu nome durante um tempo, afinal: "Tudo passa sobre a terra" (ALENCAR, 1958a, p. 304). A violência do encontro entre "branco" e "índio" marca no romance a necessidade de que uma cultura se sobreponha à outra, até aniquilá-la por completo. A frase final recai sobre os povos indígenas, sepultando-os no passado histórico brasileiro, para dar lugar à "civilização" como projeto que alia religião e estado.

\section{Esquecidos: Lourenço Amazonas, Couto de Magalhães e Gonçalves de Magalhães}

A consolidação da ideia de "raça extinta" nos textos de Gonçalves Dias e José de Alencar pode ser contraposta às produções de autores do mesmo período, relegados ao segundo escalão da literatura romântica brasileira. Lourenço da Silva Araújo Amazonas e José Vieira Couto de Magalhães, por exemplo, estavam em contato com populações indígenas e, embora tenham apresentado seus textos nas reuniões do Instituto Histórico e Geográfico Brasileiro (IHGB), geralmente em presença de D. Pedro II, foram pouco reconhecidos.

Em 1857, Lourenço Amazonas publicou o romance Simá, que só veio a ser reeditado aproximadamente 150 anos depois. No romance, o narrador conta a história da revolução de Lamalonga (1757), em que populações indígenas insurgentes contra os portugueses terminaram dizimadas. O motivo para a revolução, segundo um cronista do tempo, seria o casamento entre uma mameluca e um indígena, não aceito pelos portugueses. O narrador contesta essa versão, defendendo que o episódio do casamento serviu apenas de estopim a uma insatisfação que vinha sendo debatida entre os indígenas desde o século XVI. O romance põe em cena assembleias em que os indígenas discutem sobre o momento apropriado de abrir guerra contra os invasores. Aqueles que haviam sido "civilizados" pelas missões carmelitas defendiam que o momento não era oportuno porque o governo central havia libertado os

5 - A imagem de grupos indígenas que devem ser combatidos e exterminados ocorre até mesmo no romance Ubirajara, em que José de Alencar (1958c) inscreve a narrativa anteriormente ao contato com os colonizadores. Os tapuias fazem o papel de bárbaros e ferozes, derrotados no final pela união entre araguaias e tocantins. 
indígenas da escravidão; porque a guerra importaria o sacrifício de inocentes; porque para fazê-la tinham de se aliar aos jesuítas e aos espanhóis, desconsiderando portanto a relevância de suas ações para a pátria. Outro grupo defendia que se travasse a guerra porque a "civilização" imposta pelos portugueses desde a conquista nunca fora estruturada pela igualdade entre os povos; o indígena continuaria sendo subalterno ao português; e, desde que se libertassem do jugo dos dominadores, pouco importava aliar-se a jesuítas e espanhóis porque o conceito de pátria (como colônia portuguesa) não dizia respeito às nações indígenas.

O narrador toma partido do primeiro grupo e se contrapõe ao segundo, não porque se contraponha aos indígenas, mas porque este segundo grupo teria sido manipulado pelos jesuítas espanhóis. Apesar disso, na representação das assembleias indígenas o narrador põe o segundo grupo em primeiro plano, proferindo discursos contundentes contra a dominação portuguesa, pouco imagináveis nas obras de Gonçalves Dias e José de Alencar. No meio de uma das discussões, diz um dos indígenas:

\begin{abstract}
A categoria de país! Penso que em nada nos diz respeito, atento que não passa de questão de conveniência da administração. A franqueza de poder o indígena aspirar, como qualquer outro vassalo português, as honras e empregos na razão de sua capacidade e merecimento! que escárnio! que sarcasmo! que habilitação pode ter adquirido para as distinções sociais, o indivíduo criado na escravidão, e adrede nela embrutecido? Ide no meio dessa sociedade, a que se nos diz hoje pertencermos fraternalmente: o que observareis? O português na sala, e o indígena na cozinha! o português instruído e o indígena ignorante! o português rico, e o indígena pobre! e em resumo o azorrague do português, e as costas do indígena! sempre a indignação no coração, e o insulto na boca do português, e o sentimento no coração, e as lágrimas nos olhos do indígena!... oh que liberdade, que franquezas, que concessões!!! (AMAZONAS, 2011, p. 82-83).
\end{abstract}

A denúncia da assimetria entre indígena e português presente nessa fala justifica a posição daqueles que desejam abrir guerra contra os portugueses. No horizonte, está uma insatisfação que vinha de dois séculos antes, o questionamento da ideia de "civilização", a defesa da autonomia nas decisões sobre seus modos de vida. Os jesuítas, que o narrador pretende responsabilizar pela insurreição dos indígenas, não são personificados no romance; assim, parece que a representação dos indígenas como protagonistas de suas decisões - talvez à revelia das intenções do autor - acaba assumindo o primeiro plano.

Em 1875, quando se discutia a questão do povoamento do Brasil, o general Couto de Magalhães, funcionário do Império, escreveu $O$ selvagema pedido de $D$. Pedro II. A dissertação defendia que o indígena fosse integrado à vida do país, de 
forma a contribuir com a produção de riquezas. Propunha, como método, que fosse formado um corpo de intérpretes, aptos a catequizar os indígenas em língua Tupi; tendo ele próprio estado entre inúmeras populações indígenas, sistematizou um método de aprendizado da língua, que integra o livro. Para Couto de Magalhães, quando uma "raça civilizada" entra em contato com uma "raça bárbara", desde que possam se entender por intermédio da língua, a segunda necessariamente é assimilada à primeira. No horizonte de suas reflexões, a hierarquia entre "raças", além de tomar os indígenas como inferiores, pouco considera os negros na formação do povo brasileiro: embora num capítulo sobre a "raça atual do Brasil e de São Paulo", Magalhães (1975, p. 152) afirme que o brasileiro descende de dois troncos do Velho Mundo (o europeu e o africano) e de um tronco da América (o indígena), diz em outro momento que "Este grande colosso, que se forma ainda com o nome de Brasil, é um imenso cadinho onde o sangue europeu veio se fundir com o sangue americano" (MAGALHÃES, 1975, p. 22).

Magalhães estimava em um milhão de pessoas a população indígena do Brasil naquela época, realidade que considerava amplamente desconhecida. Assim, ele se propunha a reparar "ideias falsas" sobre o interior do Brasil, como a de que a vegetação se constituísse apenas de florestas. Em relação à concentração das populações indígenas, afirma:

\begin{abstract}
Uma outra ideia falsa que muitos formam do interior é que a população selvagem do Brasil se compõe de pequenas tribos; assim é no que respeita às que estão logo em seguida à população cristã. Mas no interior, isto é, além da linha ocupada pelos selvagens que estão em contato conosco, existem poderosas nacionalidades que não despertam a nossa atenção, porque é ainda imenso o sertão do interior que não é de forma alguma viajado ou conhecido (MAGALHÃES, 1975, p. 26).
\end{abstract}

Essa concentração representa um alerta, pois a oposição entre "cristãos" e "selvagens" poderia ser tensionada, caso estes últimos se rebelassem. Este é um motivo a mais para "amansar" os indígenas e integrá-los à nação. Nesse sentido, Couto de Magalhães não diverge dos autores do tempo, orientados para evitar que a pátria em formação fosse tomada por revoltas contra o poder central. Também a crença na religião como civilizadora do indígena era já uma ideia antiga, presente desde a Cartade Caminha, e segue sendo hegemônica até o século XX. O que me parece pouco frequente entre os discursos dos autores consagrados é a noção de que os indígenas não eram uma "raça extinta".

Talvez por isso Couto de Magalhães tenha escrito, em 1860, um conto chamado Os guayanás, em que, sob o plano histórico da fundação da cidade de São 
Paulo, o par romântico indígena tem um final feliz - verdadeira raridade na história literária brasileira ${ }^{6}$ O narrador diz ser impossível descrever a feliz existência desse casal; diante da insuficiência da linguagem para falar de coisas belas, pede à lua que o ajude a terminar a história: "Ensinai aos corações sensíveis e à humanidade sofredora que a vida pode ser um belo livro, toda vez que o amor não degenerar num sonho de moeda, num laço vil de interesse ou na torpe lascívia do materialista!" (MAGALHÃES, 1902, p. 114). Com esse final, valoriza as culturas indígenas em oposição ao modo de vida dos colonizadores; nas entrelinhas, reserva lugar especial aos padres jesuítas. Além disso, como narrativa de fundação da cidade de São Paulo, o conto oferece uma versão pouco corrente: a de que os índios seriam sujeitos históricos nesse processo.

Domingos José Gonçalves de Magalhães, ainda antes de O selvagem, tomou partido no problema do povoamento do Brasil no livro Os indígenas do Brasil perante a história[1859], escrito como comentário crítico à História geral do Brasil, de Adolfo de Varnhagen. O objetivo do livro é "reabilitar o elemento indígena" (MAGALHÃES, 2014, p. 4), frequentemente tratado de forma preconceituosa pelos historiadores. Entendia que a "civilização" amplificava tanto os vícios quanto as virtudes do ser humano, por isso se colocava entre Rousseau (que critica a civilização) e Varnhagen (que defende sua imposição de forma violenta).

O poema épico encomendado por D. Pedro II a Gonçalves de Magalhães, $A$ confederação dos Tamoios, publicado em 1856, não alcançou o sucesso esperado. José de Alencar, sob o pseudônimo de "Ig", criticou o poema em artigos de jornal, abrindo uma polêmica, na qual se envolveu o próprio imperador. Alencar acreditava que a epopeia era um gênero impróprio para cantar a natureza brasileira, cuja novidade exigia uma forma também nova, e criticava Magalhães por considerar suas personagens artificializadas segundo convenções neoclássicas. A leitura de Alencar parece, ao longo do tempo, ter se estabelecido, de tal modo que é impossível falar do poema de Magalhães sem referir a polêmica aberta por Alencar.

Como ocorre com outras epopeias encomendadas, a de Magalhães tem um objetivo político explícito: justificar a ascensão de d. Pedro II a imperador do Brasil. O enredo pode ser assim resumido: Aimbire, tamoio que já havia sido escravizado pelo

6 - Em Uma poética do genocídio, Antônio Paulo Graça (1998) analisa romances de diferentes épocas que têm um indígena como personagem central. A constatação é que, independentemente da tipologia do personagem (épica, trágica ou cômica), o indígena sempre morre no final, o que denuncia, para ele, a presença de um "inconsciente genocida", tentativa de lidar com a reiteração do crime sobre o qual a sociedade brasileira é erguida. 
português Brás Cubas depois do episódio do forte Coligny, propõe uma confederação para dar fim ao domínio português, envolvendo tamoios e franceses. Com a intercessão de Anchieta e Nóbrega, depois de iniciada a guerra, os tamoios decidem aceitar um acordo de paz. Estácio de Sá, porém, retoma o combate aos tamoios para expulsar os franceses e construir a cidade do Rio de Janeiro. Com a chegada das tropas de Mem de Sá, os tamoios são aniquilados. Aimbire é tomado pelo narrador como exemplo de fidelidade à sua pátria, embora tenha de ser sacrificado para que, futuramente, o Rio de Janeiro exista governado pelo imperador D. Pedro II.

A crítica de Magalhães a Varnhagen no comentário de 1859 pode ser dirigida ao próprio Magalhães: não estaria ele justificando "crimes inúteis" (MAGALHÃES, 2014, p. 41)? Não deveria ele deter-se ante o "horror que nos inspira qualquer prosperidade devida a um crime"(MAGALHÃES, 2014, p. 48)? O orientação final do poema parece contraditória com o desenvolvimento, em que os vilões colonizadores terminam vencendo os heróis indígenas. Para mim, a força do poema hoje está na representação dos indígenas confederados para derrotarem os portugueses. No Canto II, ao defender a guerra, Aimbire recorda a chegada de "Homens de branca pele e longas barbas, / Que posto filhos d'água parecessem, / Fogo traidor os pérfidos traziam" (II, v. 262-264). Aimbire denuncia os crimes cometidos por eles contra os povos que os receberam com generosidade. No trecho abaixo sua fala revela a indignação e a recusa em permanecer subjugado ao poder do colonizador, mais cruel do que os aimorés, inimigos dos tamoios. Nesse caso, a perspectiva de Magalhães se contrapõe à de Gonçalves Dias, que no poema "O gigante de pedra" considera a rivalidade entre povos indígenas como razão do genocídio ${ }^{7}$.

\footnotetext{
Oh dura ingratidão! Morrer por eles,

Ser mesmo em nossa terra seus escravos,

E em troco receber somente o opróbrio!

Oh dura ingratidão! O aimoré fero,

Que d'água tem horror, e sangue bebe,

O Aimoré que co'o o tigre rivaliza,

E a quem só praz a guerra e o sangue nosso,

Tanto horror, tanta infâmia não pratica.

(II, v. 278-285)
}

Mas tudo se resolverá, no poema, com a sagração do império de D. Pedro II, "Que tem por base amor e liberdade" (VI, v. 241), erguido sob a bandeira do

7 - Numa nota de Ubirajara, Alencar (1958c, p. 336) expressa opinião próxima à de Gonçalves Dias: afirma que as "guerras intestinas" entre povos indígenas rivais "aniquilaram a raça indígena, ainda mais talvez do que a crueldade dos europeus". 
cristianismo. A justificativa éformulada por São Sebastião, que Jagoanharo vê em sonho: "Tu, que n'alma só vês a liberdade, / Por quem afoito afrontarás a morte, / Sabe que o teu poder será vencido / Por um poder maior e sobre-humano, / Contra o qual dos mortais forças não valem" (VI, v. 397-401). E assim, o genocídio dos tamoios é colocado como necessário à realização do projeto divino: "A verdade da Cruz aceita e adora. / Que importa quem a traz ser inimigo, / Se o bem fica, e supera os males todos!" (VI, v. 434-436). Embora a política indígena assuma o primeiro plano, ela é posta a serviço da política indigenista.

\section{Política literária e suas consequências no presente}

A compreensão a respeito dos povos indígenas no século $\mathrm{XIX}$, presente nas obras dos cinco autores mencionados, se vinculava a um duplo debate: as teorias científicas que então surgiam a respeito das raças e a necessidade de se configurar a unidade da nação brasileira. Segundo Kaori Kodama (2009, cap. 6), no estudo que realizou sobre a etnografia do IHGB entre as décadas de 1840 e 1860, as "nações" indígenas eram pensadas na medida em que davam lugar à "nação" brasileira. Distinguia-se o tupi como indígena "puro", inexistente porque já "assimilado", do tapuia do sertão, falante de outras línguas, considerado "bárbaro". Assim, a divisão entre aliados e inimigos, ao mesmo tempo em que justificava o genocídio do segundo grupo, tornava o primeiro objeto do passado. Naquele momento havia, portanto, pouco espaço para a presença indígena na sociedade: ou eram "selvagens" a ser "convertidos" e "assimilados", ou eram inimigos a ser exterminados. No horizonte futuro, não haveria mais "índio" no Brasil.

Se a ciência do século XIX que hierarquizava pessoas segundo critérios raciais é hoje amplamente questionada, a literatura produzida em diálogo com ela permanece em muitas instâncias da sociedade como coisa atemporal. A imagem da literatura, enquanto artefato estético produzido por homens geniais à frente do seu tempo, confere um poder desmedido ao discurso literário. É como se a presença de uma obra no cânone a livrasse dos limites e contradições do seu tempo.

A inserção e permanência de uma obra no cânone é um processo para o qual certamente contribuem muitas razões, sobre as quais não é possível dizer que haja consenso. Embora eu não considere que motivos estéticos são alheios a motivos ideológicos, acredito que haveria uma série de questões estéticas capazes de motivar a reavaliação da marginalidade dos autores elencados entre os "esquecidos". Apenas 
a título de exemplo, algumas "novidades" formais encontradas em suas obras: Lourenço Amazonas constrói um romance histórico com um narrador irônico, que dialoga e ri do leitor e da leitora, o qual poderia ser relacionado ao narrador machadiano; Couto de Magalhães escreve um conto em que o final feliz para o casal indígena coloca questões formais para a representação dos indígenas naquele momento e ainda hoje; Gonçalves de Magalhães produz uma epopeia em que o herói não vence no final e os vilões têm seus crimes justificados, o que, se comparado ao modelo de epopeia camoniana, representaria uma inovação estética.

Nas obras de Gonçalves Dias e José de Alencar as personagens indígenas são vítimas do processo histórico (se rendem ao destino trágico, reconhecem sua própria sujeição); nas obras de Lourenço Amazonas, Couto de Magalhães e Gonçalves de Magalhães, as personagens indígenas são representadas como agentes históricos (lutam, discursam, se rebelam, vivem). Se, como acredito, forma e conteúdo não se separam e, consequentemente, motivos estéticos são também motivos ideológicos, pergunto: a forma literária que representava mais coerentemente a política indigenista da época não teria tido mais aceitação do que a forma literária que representava a política indígena em ação? Em outras palavras: a representação das lutas indígenas contra o colonizador não teria contribuído para a marginalidade de obras como Simá e A confederação dos Tamoios?

Se a resposta for afirmativa, poderíamos dizer que há relação entre valores sociais e produção do reconhecimento de autores e obras literárias. O pouco espaço para a presença indígena no Brasil do século XIX parece coerente com 0 reconhecimento de textos literários que fixam os povos indígenas num passado a ser superado. Além de reforçar a ideia de que obras literárias são atemporais, a permanência hoje desses textos no cânone escolar sem que outros discursos sejam a eles somados, estabelece uma continuidade com esse passado histórico que mereceria ser rompida. A Lei 11.645/2008, que prevê o estudo da história e cultura indígena em todas as disciplinas do currículo escolar nos sistemas de ensino brasileiros, ainda não surtiu os efeitos esperados, no sentido de somar outras vozes e outras maneiras de pensar a questão indígena no passado e no presente.

O imaginário social a respeito dos povos indígenas hoje talvez deva muito à configuração forjada por autores canônicos do romantismo brasileiro, reforçada por outros tipos de discurso (político, científico, jornalístico, cinematográfico, midiático, publicitário etc.). À revelia da proposta do próprio José de Alencar - que conscientemente realizava um trabalho de idealização do indígena para que suas 
personagens pudessem fazer frente às personagens de romances europeus -, o "índio romântico" se tornou uma imagem hegemônica ${ }^{8}$ : o eterno Peri, seminu, de arco e flechas a postos para defender a mocinha da história. Transposta sem as devidas mediações para o mundo real, essa imagem indicia o poder desmedido atribuído à literatura. Esse poder legitima a exclusão social dos povos indígenas, fixando-os no passado; quando emergem no presente, contrapostos a essa imagem, não são reconhecidos.

Compreender a política literária em seu contexto, os discursos conflitantes, as experiências postas em segundo plano, pode ajudar a ampliar os horizontes de representação. A imagem do "índio romântico", herói sacrificado para a emergência do sentimento de unidade nacional, falsifica a diversidade de experiências e modos de vida possíveis no horizonte do presente. Por enquanto, o discurso hegemônico tem logrado homogeneizar a imagem do indígena; quem sabe, para o futuro, consigamos tornar hegemônica a ideia de diversidade, essa palavra que vem sendo esvaziada pelo pouco alcance a que nossa imaginação tende a lançá-la.

No Brasil, desde as últimas décadas do século $X X$, a presença de autores e autoras indígenas, articulados em um movimento nacional, tem se contraposto à representação limitadora da experiência indígena no passado e no presente. Lendo seus textos, tenho pensado na necessidade de desaprender. Mas este é um assunto para outras páginas...

Finalizo com palavras de Ailton Krenak (2019, p. 28-33) - em palestra proferida em Lisboa no dia 12 de março de 2019, recolhida em Ideias para adiar o fim do mundo - que recuperam o histórico de resistência dos povos originários contra um projeto de civilização por muitos deles recusado e afirmam a necessidade de sermos plurais:

\begin{abstract}
Como os povos originários do Brasil lidaram com a colonização, que queria acabar com o seu mundo? Quais as estratégias esses povos utilizaram para cruzar esse pesadelo e chegar ao século XXI ainda esperneando, reivindicando e desafinando o coro dos contentes? Vi as diferentes manobras que os nossos antepassados fizeram e me alimentei delas, da criatividade e da poesia que inspirou a resistência desses povos. A civilização chamava aquela gente de bárbaros e imprimiu uma guerra sem fim contra eles, com o objetivo de transformá-los em civilizados que poderiam integrar o clube da humanidade. [...]
\end{abstract}

Às vezes, os antropólogos limitam a compreensão dessa experiência, que não é só cultural. [...] Quantos perceberam que essas estratégias só tinham

8 - Dispenso-me aqui de comprovar essa afirmação. Bastaria ler comentários em matérias de jornal para se verificar o tratamento preconceituoso e reducionista com que muitas pessoas se expressam quando não se veem diante do "índio romântico". 
como propósito adiar o fim do mundo? Eu não inventei isso, mas me alimento da resistência continuada desses povos [...].

Cantar, dançar e viver a experiência mágica de suspender o céu é comum em muitas tradições. Suspender o céu é ampliar o nosso horizonte; não o horizonte prospectivo, mas um existencial. $\dot{E}$ enriquecer as nossas Subjetividades, que é a matéria que este tempo que nós vivemos quer consumir. Se existe uma ânsia por consumir a natureza, existe também uma por consumir subjetividades - as nossas subjetividades. Então vamos vivêlas com a liberdade que formos capazes de inventar, não botar ela no mercado. Já que a natureza está sendo assaltada de uma maneira tão indefensável, vamos, pelo menos, ser capazes de manter as nossassubjetividades, nossas visões, nossas poéticas sobre a existência. Definitivamente não somos iguais, e é maravilhoso saber que cada um de nósaqui é diferente do outro, comoconstelações. O fato de podermos compartilhar esse espaço, de estarmos juntos viajando não significa que somos iguais; significa que somos capazes de atrair uns aos outros pelas nossas diferenças, que deveriam guiar o nosso roteiro de vida. Ter diversidade, não isso de uma humanidade com o mesmo protocolo. Porque isso até agora foi só uma maneira de homogeneizar e tirar nossa alegria de estar vivos.

\section{Referências bibliográficas}

ALENCAR, José de. Cartas sobre A confederação dos Tamoios. Em: Obra completa, vol. 4. Rio de Janeiro: José Aguilar, 1960, p. 863-922.

ALENCAR, José de. Iracema. Em: Obra completa, vol. 3. Rio de Janeiro: José Aguilar, 1958a, p. 223-320.

ALENCAR, José de. O Guarani. Em: Obra completa, vol. 2. Rio de Janeiro: José Aguilar, 1958b, p. 5-399.

ALENCAR, José de. Ubirajara. Em: Obra completa, vol. 3. Rio de Janeiro: José Aguilar, 1958c, p. 321-404.

AMAZONAS, Lourenço da Silva Araújo. Simá: romance histórico do Alto Amazonas. Manaus: Editora Valer, 2011.

BOSI, Alfredo. Dialética da colonização. São Paulo: Companhia das Letras, 1992.

CUNHA, Manuela Carneiro da. Índios no Brasil: história, direitos e cidadania. São Paulo: Claro enigma, 2012.

DIAS, Gonçalves. Cantos. São Paulo: Martins Fontes, 2000.

FRANCHETTI, Paulo. Estudos de literatura brasileira e portuguesa. Cotia, SP: Ateliê Editorial, 2007.

GRAÇA, Antônio Paulo. Uma poética do genocídio. Rio de Janeiro: Topbooks, 1998.

KODAMA, Kaori. Os índios no Império do Brasil: a etnografia do IHGB entre as décadas de 1840 e 1860. Rio de Janeiro: Editora FIOCRUZ; São Paulo: EDUSP, 2009.

KRENAK, Ailton. Ideias para adiar o fim do mundo. São Paulo: Companhia das Letras, 2019.

HELENA, Lucia. A solidão tropical: o Brasil de Alencar e da modernidade. Porto Alegre: EDIPUCRS, 2006. 
MAGALHÃES, Domingos José Gonçalves de. A confederação dos Tamoios. In: TEIXEIRA, Ivan (org.). Épicos. São Paulo: Editora da Universidade de São Paulo; Imprensa Oficial do Estado de São Paulo, 2008.

MAGALHÃES, Domingos José Gonçalves de. Os indígenas do Brasil perante a história. Trans/usofonias - Revista de Estudos Comparativistas Lusófonos da UFTPR, vol. 1, n. 1, 2014.

MAGALHÃES, José Vieira Couto de. Os Guayanás: conto histórico sobre a fundação de São Paulo. São Paulo: Typ. Espindola, 1902.

MAGALHÃES, José Vieira Couto de. O selvagem. Belo Horizonte: Ed. Itatiaia; São Paulo: Ed. da Universidade de São Paulo, 1975. 